\title{
Awareness of Buffalo Owner about Causes of Buffalo Infertility
}

\author{
A. C. Vaidya ${ }^{1 *}$, S. J. Jadav ${ }^{2}$ and B. R. Barasara ${ }^{3}$ \\ ${ }^{1}$ Krishi Vigyan Kendra, Dahod, ${ }^{2}$ Dairy Vigyan Kendra, SMC College of Dairy Science, \\ Anand Agricultural University, Anand, Gujarat, India \\ ${ }^{3}$ Veterinary Officer, MVD, Govt. of Gujarat, Surendranagar, India \\ *Corresponding author
}

\section{A B S T R A C T}

\section{Keywords}

Awareness, Buffalo owner, Infertility

Article Info

Accepted:

12 October 2020

Available Online:

10 November 2020
The study was emphasized on awareness of buffalo owner about causes of buffalo infertility in Panchmahals district (Gujarat). Total 200 buffalo owners were selected with using simple random sampling method from 20 villages of 5 talukas of Panchmahals district. There was 62.00 percent of buffalo owners had medium level of awareness about causes of buffalo infertility. An arrangement of major components of buffalo owner's awareness level about causes of buffalo infertility as 'General breeding \& breeding methods $\rightarrow$ Breeding time \& length $\rightarrow$ Feeding effect on reproduction $\rightarrow$ Health and diseases regarding infertility' ordered in decreasing trend. Correlation ( $r$ ) between awareness of buffalo owner about causes of buffalo infertility and annual income, landholding, extension contact, education and participation in livestock training programme were found to be highly significant at 0.01 level of significance. The study was found that areas of buffalo infertility should more focus by buffalo owners and veterinary extension agencies on brucellosis disease in reference to animal infertility, causes of repeat breeding, balance feeding in reference to animal fertility and other general information regarding animal breeding.

\section{Introduction}

Milk production of India was187.7 million tonnes and Gujarat state produced 14.49 million tonnes in the year of 2018-19. Total buffalo population of India is 109.85 million and Gujarat state has 10.54 million buffalo (20 ${ }^{\text {th }}$ Livestock census 2019). The total milk production of buffalo was 7.26 million tonnes in the Gujarat state during 2018-19, which contributed $50.08 \%$ of total state milk production. Buffaloes are the backbone of rural economy in many developing countries of the Asian region including India. Buffaloes occupy a prominent place in the social, economic and cultural life of Indian rural communities and are useful as a triple purpose animal for milk, meat and draft power (Kishore et al., 2013). Panchmahals district has 4.43 lakhs productive buffalo and their average milk yield per day is $2.33 \mathrm{~kg}$ which is far lower than state average buffalo milk productivity $(3.28 \mathrm{~kg})\left(36^{\text {th }}\right.$ Survey ReportMajor livestock products Gujarat state). Several factors are responsible for this low production. Reproduction is one of the most 
important considerations determining the profitability of dairy animal production (Dhaka et al., 2017). So, researchers want to understand the awareness level of buffalo owner about causes of buffalo infertility in Panchmahals district (Gujarat).

\section{Materials and Methods}

The study was conducted in the Panchmahals district. Five talukas of Panchmahals district were randomly selected for the study. Four villages from each taluka were selected randomly. Ten buffalo owners from each selected village were randomly selected. Thus, total200 buffalo owners were selected for the present study. An interview schedule was developed in line with the objectives of the study with the help of experts of animal Gynaecology. The selected buffalo owners were interviewed by contacting them at their doorstep. While collecting data adequate time was given to the buffalo owner to arrive at values by the memory recall method. The family members of the buffalo owners were also involved in the collection of data to get correct information as far as possible. Data were analysed with IBM SPSS Statistics version-21.

\section{Results and Discussion}

Data presented in Table 1 revealed that there was 74.50 percent of the buffalo owners were from middle aged group and96.00 percent buffalo owners were found to be literate. More than half $(55.00 \%)$ of the buffalo owners had 1.01 to 2.00 hectares land. There was 45.50 percent buffalo owners earned Rs. $50,001 /-$ to $1,00,000 /-$ rupees annually. The respondents $(37.00 \%)$ had kept only buffalo in their farm followed by buffaloes and crossbred cows (35.00\%), buffaloes and indigenous cows $(18.00 \%)$ and buffaloes + crossbred cow + indigenous cows $(10.00 \%)$ which was found to be least. Nearly half
$(48.00 \%)$ of the respondents were keeping Surti buffalo followed by Mehsani buffalo $(30.00 \%)$ and non-descript type of buffalos $(22.00 \%)$. Buffalo owners $(37.00 \%)$ had medium level of extension contact. Contrast result was found by (Jadav and Raval, 2019), who observed that dairy farmers $(38.33 \%)$ fell in low extension participation group. There was 19.00 percent of buffalo owners had participated in any livestock training programme.

Data presented in Table 2 indicated that majority of buffalo owners was well aware about 'buffalo can be bred with natural and artificial insemination (AI)' technique both and consult veterinarian if retention of placenta (ROP) persists for 12 hrs. (91.00\%) followed by symptoms of heat $(90.50 \%)$, oestrus length $(89.00 \%)$, calf must be offer colostrum within half an hour after calving $(86.50 \%)$ and prolapse creates problems in calving $(82.00 \%)$. There was almost fifty percent of buffalo owners aware about benefits of AI upon NS (57.00\%), correlation between mastitis and reproduction (55.00\%), good quality concentrate feed essential for regular oestrous $(52.50 \%)$, days required for confirmation of pregnancy after breeding $(49.50 \%)$, days required for return in heat if not conceived $(49.00 \%)$, ideal time for breeding after coming in heat $(45.50 \%)$ and quantity of mineral mixture to be fed to buffalo (44.00\%). There was less awareness among the buffalo owners about deficient of certain feed ingredients prevent oestrus $(20.50 \%)$, days required to heat after calving $(24.50 \%)$, buffalo requires balance feed for regular oestrous $(25.50 \%)$, ideal weight of heifer at first oestrous (28.50\%), importance of mineral mixture for regularity in oestrous, conceiving and time being delivery $(30.50 \%)$, discharge of buffalo considered as normal discharge $(32.00 \%)$ and days required to breed after calving (33.50\%). There was very less buffalo owners aware about corpus 
luteum and brucellosis infected buffalo even if conceived may abort (05.50\%), brucellosis is one of the reason behind irregular heat $/$ repeat breeding $(06.50 \%)$, causes of repeat breeding syndrome $(07.00 \%)$, irregular heat due to endocrinological problems $(09.00 \%)$ and payometra in buffalo (10.00\%). Dhaka et al (2017) reported that that there was relatively high prevalence of reproductive disorders in buffaloes in Bundi district of Rajasthan. This might have been due to poor management practices followed by the farmers and inefficient veterinary extension services.

Table.1 Distribution of buffalo owners according to their characteristics $(\mathrm{n}=200)$

\begin{tabular}{|c|c|c|c|}
\hline $\begin{array}{l}\text { Sr. } \\
\text { No. }\end{array}$ & Characteristic & Category & $\begin{array}{l}\text { No. (\%) of } \\
\text { participants }\end{array}$ \\
\hline \multirow[t]{3}{*}{1} & \multirow[t]{3}{*}{ Age } & Young ( $\leq 30$ years) & $11(05.50)$ \\
\hline & & Middle aged (31-50 Years) & $149(74.50)$ \\
\hline & & Old $(>50$ Years $)$ & $40(20.00)$ \\
\hline \multirow[t]{5}{*}{2} & \multirow[t]{5}{*}{ Education } & Illiterate & $8(04.00)$ \\
\hline & & Up to primary education & $84(42.00)$ \\
\hline & & Up to secondary education & $64(32.00)$ \\
\hline & & Up to higher secondary education & $26(13.00)$ \\
\hline & & Graduate and above & $18(09.00)$ \\
\hline \multirow[t]{5}{*}{3} & \multirow[t]{5}{*}{ Land holding } & Landless farmers & $0(0.00)$ \\
\hline & & Marginal farmer (Up to $1.00 \mathrm{ha}$ ) & $60(30.00)$ \\
\hline & & Small farmer (1.01 to $2.00 \mathrm{ha})$ & $110(55.00)$ \\
\hline & & Medium farmer (2.01 to $4.00 \mathrm{ha}$ ) & $26(13.00)$ \\
\hline & & Large farmer (Above 4.00 ha) & $4(02.00)$ \\
\hline \multirow[t]{5}{*}{4} & \multirow[t]{5}{*}{ Annual income } & Up to Rs. $50,000 /-$ & $35(17.50)$ \\
\hline & & Rs. $50,001 /-$ to $1,00,000 /-$ & $91(45.50)$ \\
\hline & & Rs. $1,00,001 /-$ to $1,50,000 /-$ & $38(19.00)$ \\
\hline & & Rs. $1,50,001 /-$ to $2,00,000 /-$ & $28(14.00)$ \\
\hline & & More than Rs.2,00,000/- & $8(04.00)$ \\
\hline \multirow{4}{*}{5} & \multirow[t]{4}{*}{ Livestock Composition } & Buffaloes & $74(37.00)$ \\
\hline & & Buffaloes + Indigenous cows & $36(18.00)$ \\
\hline & & Buffaloes + Crossbred cows & $70(35.00)$ \\
\hline & & $\begin{array}{l}\text { Buffaloes + Crossbred cows + } \\
\text { Indigenous cows }\end{array}$ & $20(10.00)$ \\
\hline \multirow[t]{3}{*}{6} & Breeds of buffalo & Surti & $96(48.00)$ \\
\hline & & Mehsani & $60(30.00)$ \\
\hline & & Non-descript & $44(22.00)$ \\
\hline \multirow[t]{4}{*}{7} & \multirow{4}{*}{ Extension contact } & Low $(\overline{\mathrm{X}}-1 / 2 \mathrm{SD})$ & $56(28.00)$ \\
\hline & & $\operatorname{Medium}(\overline{\mathrm{X}} \pm 1 / 2 \mathrm{SD})$ & $74(37.00)$ \\
\hline & & $\operatorname{High}(\overline{\mathrm{X}}+1 / 2 \mathrm{SD})$ & $70(35.00)$ \\
\hline & & $(\overline{\mathrm{X}}=3.69, \mathrm{SD}=1.60)$ & \\
\hline \multirow[t]{2}{*}{8} & \multirow{2}{*}{$\begin{array}{l}\text { Participation in any livestock } \\
\text { training programme }\end{array}$} & Yes & $38(19.00)$ \\
\hline & & No & $162(81.00)$ \\
\hline
\end{tabular}


Table.2 Distribution of buffalo owners according to their awareness about causes of buffalo infertility $(n=200)$

\begin{tabular}{|c|c|c|}
\hline $\begin{array}{l}\text { Sr. } \\
\text { No. }\end{array}$ & Different causes for infertility in buffalo & $\begin{array}{l}\text { No. }(\%) \text { of } \\
\text { participants }\end{array}$ \\
\hline $\mathbf{A}$ & \multicolumn{2}{|l|}{ Regarding time \& length } \\
\hline 1 & Length of oestrous & $178(89.00)$ \\
\hline 2 & Ideal time for breeding after coming in heat & $91(45.50)$ \\
\hline 3 & Days require for confirmation of pregnancy in after breeding & $99(49.50)$ \\
\hline 4 & If buffalo not conceived, days required for return in heat & $98(49.00)$ \\
\hline 5 & Length of gestation & $121(60.50)$ \\
\hline 6 & Days required to heat after calving & $49(24.50)$ \\
\hline 7 & Days required to breed after calving & $67(33.50)$ \\
\hline B & \multicolumn{2}{|l|}{ Regarding general breeding \& breeding methods } \\
\hline 8 & Symptoms of heat & $181(90.50)$ \\
\hline 9 & Mating age of buffalo heifer & $130(65.00)$ \\
\hline 10 & Buffalo can be bred with natural and artificial insemination. & $182(91.00)$ \\
\hline 11 & $\begin{array}{l}\text { AI should be repeated if clean discharge continuous even on next day of } \\
\text { previous AI. }\end{array}$ & $137(68.50)$ \\
\hline 12 & Benefits of AI upon NS & $114(57.00)$ \\
\hline 13 & Discharge of buffalo considered as normal discharge & $64(32.00)$ \\
\hline 14 & Ideal weight of heifer at first oestrous & $57(28.50)$ \\
\hline 15 & Corpus luteum & $11(05.50)$ \\
\hline $\mathbf{C}$ & \multicolumn{2}{|l|}{ Regarding feeding effect on reproduction } \\
\hline 16 & Buffalo requires balance feed for regular oestrous & $51(25.50)$ \\
\hline 17 & Deficient of certain feed ingredients prevent oestrus & $41(20.50)$ \\
\hline 18 & Provide sufficient quantity of green and dry fodder for regular oestrous & $124(62.00)$ \\
\hline 19 & Good quality concentrate feed essential for regular oestrous & $105(52.50)$ \\
\hline 20 & Calf must be offer colostrum within half an hour after calving & $173(86.50)$ \\
\hline 21 & $\begin{array}{l}\text { Importance of mineral mixture for regularity in oestrous, conceiving and } \\
\text { time being delivery }\end{array}$ & $61(30.50)$ \\
\hline 22 & Quantity of mineral mixture to be fed to buffalo & $88(44.00)$ \\
\hline $\mathbf{D}$ & \multicolumn{2}{|l|}{ Regarding health \& diseases } \\
\hline 23 & Brucellosis is one of the reason behind irregular heat / repeat breeding & $\begin{array}{c}13 \\
(06.50)\end{array}$ \\
\hline 24 & Brucellosis infected buffalo even if conceived may abort & $11(5.50)$ \\
\hline 25 & Irregular heat due to endocrinological problems & $18(9.0)$ \\
\hline 26 & $\begin{array}{l}\text { Physio-anatomical disorder in reproductive organs lead to fertility } \\
\text { failure }\end{array}$ & $29(14.50)$ \\
\hline 27 & Causes of repeat breeding syndrome & $14(7.00)$ \\
\hline 28 & Problematic to conceive buffalo having kinked cervix & $46(23.0)$ \\
\hline 29 & Prolapse creates problems in calving & $164(82.00)$ \\
\hline 30 & Consult veterinarian if retention of placenta persists for $12 \mathrm{hrs}$. & $182(91.00)$ \\
\hline 31 & Whitish discharge is normal & $72(36.00)$ \\
\hline 32 & Under developed reproductive organs leads to infertility & $26(13.00)$ \\
\hline 33 & Payometra in buffalo & $20(10.00)$ \\
\hline 34 & Correlation between mastitis and reproduction & $110(55.00)$ \\
\hline
\end{tabular}


Table.3 Awareness level of buffalo owners regarding different components of infertility in buffalo $\quad(n=200)$

\begin{tabular}{|c|l|c|}
\hline Sr. No. & Components & Percentage \\
\hline $\mathbf{1}$ & Regarding time \& length & 50.21 \\
\hline $\mathbf{2}$ & Regarding general breeding \& breeding methods & 54.75 \\
\hline $\mathbf{3}$ & Regarding feeding effect on reproduction & 45.93 \\
\hline $\mathbf{4}$ & Regarding health \& diseases & 29.38 \\
\hline
\end{tabular}

Table.4 Overall awareness of buffalo owners about causes of buffalo infertility ( $\mathrm{n}=200)$

\begin{tabular}{|c|l|c|c|}
\hline Sr.No. & \multicolumn{1}{|c|}{ Awareness category } & Frequency & Percentage \\
\hline $\mathbf{1}$ & Low level (up to 33.33\%) & 56 & 28.00 \\
\hline $\mathbf{2}$ & Medium level (33.34 to 66.66\%) & 124 & 62.00 \\
\hline $\mathbf{3}$ & High level (>66.66 \%) & 20 & 10.00 \\
\hline
\end{tabular}

Table.5 Correlation (r) between the profile of buffalo owner and awareness of buffalo owner about causes of buffalo infertility $(n=200)$

\begin{tabular}{|c|l|c|}
\hline Sr.No. & Variables & $\begin{array}{c}\text { Pearson 'r' value } \\
\text { (Awareness) }\end{array}$ \\
\hline $\mathbf{1}$ & Age & $0.075^{\mathrm{NS}}$ \\
\hline $\mathbf{2}$ & Education & $0.252^{* *}$ \\
\hline $\mathbf{3}$ & Land holding & $0.278^{* *}$ \\
\hline $\mathbf{4}$ & Annual Income & $0.394^{* *}$ \\
\hline $\mathbf{5}$ & Extension Contact & $0.273^{* *}$ \\
\hline $\mathbf{6}$ & $\begin{array}{l}\text { Participation in livestock } \\
\text { training programme }\end{array}$ & $0.251^{* *}$ \\
\hline & $\begin{array}{l}\text { *. Correlation is significant at the } \mathbf{0 . 0 5} \text { level (2-tailed). } \\
\text { **. Correlation is significant at the 0.01 level (2-tailed). }\end{array}$ \\
\hline
\end{tabular}

Table 3 indicated that there was found that buffalo owners was 54.75 percent aware about general breeding \& breeding methods followed by breeding time \& length $(50.21 \%)$ and feeding effect on reproduction $(45.93 \%)$ in the study area. When we discuss on buffalo health and diseases regarding infertility it was found to be low $(29.38 \%)$.

It is observed in table 4 that there was 62.00 percent of buffalo owners had medium level of awareness about causes of infertility followed by 28.00 and 10.00 percent of them were low and high level of awareness about causes of buffalo infertility, respectively. It was found in table 5 that correlation (r) between awareness of buffalo owners about causes of buffalo infertility and annual income (0.394), landholding (0.278), extension contact (0.273), education (0.252) and participation in livestock training programme $(0.251)$ were found to be highly significant. The study found that awareness level of buffalo owner was increased with increasing the buffalo owner's education \& economic condition. 
It is concluded that more than half of buffalo owners had medium level of awareness about causes of buffalo infertility (Table 4) in the Panchmahals district. Buffalo owners had more than fifty percent awareness regarding breeding \& breeding methods and breeding time \& length and less than fifty percent awareness regarding feeding effect on animal reproduction but very less awareness about animal health \& diseases with relation to animal infertility (Table 3). Training programme, awareness programme, literature and other extension activities should be provided to buffalo owners on buffalo breeding especially focus on animal nutrition, animal health \& its importance on animal fertility. Animal infertility camp should be organize for diagnosis various causes of buffalo infertility at village level.

\section{References}

$20^{\text {th }}$ Livestock census 2019-All India Report. Ministry of Fisheries, Animal Husbandry \& Dairying. Department of Animal Husbandry \& Dairying. Animal Husbandry Statistics Division,
KrishiBhawan, New Delhi, India.

$36^{\text {th }}$ Survey report Major livestock products for the year 2018-2019 on estimates of Gujarat state. Directorate of Animal Husbandry, KrishiBhavan, Sector 10-A Gandhinagar - 382 010, Gujarat State.

Dhaka, B.L., G.S. Meena and Meena, N.L. 2017. Reproductive Performance of Buffaloes under Field Conditions in Bundi District of Rajasthan. International Journal of Current Microbiology and Applied Sciences. 6(4): 595-599. https://doi.org/10.20546/ ijcmas.2017.604.071

Jadav, S. J., and Raval, S. K. 2019. Consciousness of Dairy Farmers about Brucellosis. International Journal of Current Microbiology and Applied Sciences.8 (09): 1404-1415. https://doi.org/10.20546/ijcmas.2019.80 9.161

Kishore, K., M. Mahender and Ch. Harikrishna. 2013. A study on buffalo management practices in Khammam district of Andhra Pradesh. Buffalo Bulletin. 32(2): 97-119.

\section{How to cite this article:}

Vaidya, A. C., S. J. Jadav and Barasara, B. R. 2020. Awareness of Buffalo Owner about Causes of Buffalo Infertility. Int.J.Curr.Microbiol.App.Sci. 9(11): 1331-1336.

doi: https://doi.org/10.20546/ijcmas.2020.911.156 